\title{
Of wildcats and wild cats: troubling species-based conservation in the Anthropocene
}

\author{
Aurora Fredriksen \\ The University of Manchester, School of Environment, Education and Development \\ Arthur Lewis Building, Manchester M13 9PL, United Kingdom \\ aurora.fredriksen@manchester.ac.uk
}

Forthcoming in Environment and Planning D: Society and Space

(post-peer review author created PDF)

\begin{abstract}
This article takes the case of Scottish wildcats, threatened with extinction through hybridisation with feral domestic cats, as a site for exploring what it means to conserve a species as such. To this end, the article looks at the practices associated with conserving Scottish wildcats as defined by a definite phenotypical, morphological and/or genetic type, abstracted from indefinite, fleshy organisms emplaced and entangled within changing ecologies. The article describes the biopolitical work of taxonomically distinguishing wildcats (Felis silvestris) from domestic cats (Felis catus) and their hybrids, exploring the challenges presented to this work by the disorderly agencies of wild-living cats. It then outlines and reflects on the proposed captive breeding programme aimed at preserving the 'pure' Scottish wildcat sub-species type. This case highlights the ways in which species-based conservation can conflict with care for individual animals as well as with life's immanent, generative tendencies.
\end{abstract}

Keywords: conservation biology, species, hybridisation, biopolitics, inventive life, Scottish wildcats 
Of wildcats and wild cats: troubling species-based conservation in the Anthropocene

Aurora Fredriksen

The last surviving wild member of the Felidae (i.e., cat) family in Britain, the Scottish wildcat is an elusive animal with the appearance of a large tabby cat with a bushy black ringed tail. With as few as 400 left, it is among the most endangered species in the UK (Scottish Natural Heritage 2013). Threats to the survival of wildcats in Scotland include the familiar perils of habitat loss and fragmentation and illegal killing by humans. However, the biggest threat to Scottish wildcats, according to those charged with their conservation, is neither the loss of habitat nor direct killings, but rather the growing presence of feral domestic cats in 'wild' Scottish landscapes (Scottish Natural Heritage 2013). Rather than the familiar scenario of an 'invasive' species outcompeting a 'native'1 one for resources, the presence of feral domestic cats in territories inhabited by wildcats presents a different sort of problem for conservationists: within shared spaces of Scottish wild(er)ness (Whatmore and Thorne 1998), wildcats and feral cats interbreed to produce healthy offspring that in turn interbreed with wildcats, feral cats and fellow hybrids. The threat posed to wildcats by feral cats, then, is one of introgression: the movement of genes from one species or subspecies into the gene pool of another through repeated interbreeding and backcrossing between the two. Thus, the fear of conservationists is that wildcats and feral domestic cats are becoming one indistinguishable group of wild-living cats in Scotland and, in time, the 'pure' Scottish wildcat type will become extinct.

The spectre of extinction through introgression or, to use the more colloquial if less accurate term, hybridisation is not unique to Scottish wildcats. Similar conservation alarms have been raised, for example, in the cases of endangered Grevy's zebras hybridising with common plains zebras (Cordingley et al. 2009), European wolves hybridising with feral dogs (Butler 1994) and North American red wolves hybridising with eastern coyotes (Fredrickson and Hedrick 2006, Braverman 2015). Reports have

\footnotetext{
${ }^{1}$ I use inverted commas around 'invasive' and 'native' here to signal that, following from van Dooren (2011), I find these descriptors more useful for describing the human framings of which plants and animals belong in certain places and which do not, than for describing inherent qualities of living organisms.
} 
even started to emerge of polar bears - the mascots and martyrs of the threats posed to wildlife by anthropogenic climate change - hybridizing with grizzly bears (e.g., Höflinger 2012). Beyond such prominent mammalian cases, numerous examples have been observed in bird, fish, and plant populations (for more comprehensive reviews of the matter, see Rhymer and Simberloff 1996; Schwenk, Brede, and Streit 2008; Stronen and Paquet 2013; Ward et al. 2012). Yet, although the phenomenon of threatened extinction through hybridisation is much wider than the case of Scottish wildcats, it remains an oddity in a time where anthropogenic biodiversity loss has escalated to the point where many agree we are living through Earth's sixth mass extinction event (e.g., Leakey and Lewin 1995; Barnosky et al. 2011; Dirzo et al. 2014; Kolbert 2014). As this article will demonstrate, however, the peculiar case of threatened extinction through hybridisation directs attention to a fundamental question for this time of escalating extinctions and precipitous defaunation $^{2}$ : namely, what does it means to conserve a species as such? Species, as Braverman $(2014,2015)$ points out, are the 'basic unit' of conservation biology. At the same time, as a number of scholars have pointed out, the care and preservation of a species can come at the expense of care for individual animals, effecting a biopolitical hierarchy of valued and unvalued lives (e.g. Braverman 2014, Chrulew 2011, Lulka 2004, van Dooren 2014). In this article I consider the biopolitics inherent in current Scottish wildcat conservation efforts, but I also consider the multiple ways in which the unruly, embodied lives of wild-living cats in Scotland escape and unsettle these biopolitical conservation regimes. As the case of Scottish wildcat conservation shows, species-based conservation not only undermines care for and the autonomy of individual animals, but also runs up against life's immanent, disorganising tendencies to "become otherwise" (Lorimer and Driessen 2013b, 255; after Deleuze and Guattari 1987).

The article proceeds as follows: The next section situates the case within emerging discourses of the Anthropocene and the scholarly literatures on conservation biopolitics and inventive life. This is followed by a brief account of the biogeographies of Scottish wildcats and a discussion of the (imagined) place of wildcats and feral domestic cats in Scotland's 'wild' landscapes. Next, I describe the taxonomic and genetic work of

\footnotetext{
2 The term 'defaunation' denotes the reduction in the abundance of animals, including ones still considered common (Dirzo et al, 2014).
} 
Fredriksen - 'Of wildcats and wild cats' (author created pdf, post peer review)

ordering different types of cats and the difficultly presented to this work by the disorderly worlds of wild-living cats. I then outline the proposed captive breeding programme aimed at preserving a 'pure' Scottish wildcat type. The conclusion returns to the question of what it means to conserve a species as such, reflecting normatively on the inadequacy of species-centred conservation in the Anthropocene. The empirical material presented here draws on scientific literature, policy documents, popular media and grey literature as well as on a handful of interviews with experts in Scottish wildcat conservation.

\section{Conserving species in the Anthropocene}

The acceleration and accumulation of anthropogenic changes to various Earth systems over the past 300 years has led to the suggestion that we have entered a new geographical epoch, the Anthropocene (Ellis 2011; Castree 2014). First coined by the chemist Paul Crutzen in the early 2000s, the term Anthropocene has recently been gaining parlance in the geosciences (Zalasiewicz et al 2008), ecology (Ellis 2015; Williams et al 2015), the social sciences (Castree et al 2014) and beyond. With its implication that there is no pure 'Nature' untouched by human society, the ontology of the Anthropocene resonates with longstanding calls in the social sciences to do away with ideas of nature outside of human society (e.g., Castree, 2005; Cronan, 1995; Whatmore and Thorne 1998) and dualistic thinking about nature and culture/society more broadly (e.g., Haraway 1991; Latour, 1993; Whatmore, 2001).

In the field of conservation, the increasingly apparent anthropogenic changes to Earth systems (especially climate) heralded by the Anthropocene and the failure of traditional conservation practices to halt defaunation have compelled a growing group of practitioners, chroniclers and academics to call for new ways of doing conservation. Examples from this emerging body of approaches include rewilding experiments (see, for example, Donlan 2005; Lorimer and Driessen 2013a; Lorimer and Driessen 2013b; Soulé and Noss 1998), assisted migration (e.g., Lunt et al. 2013; McLachlan, Hellmann, and Schwartz 2007; Miller et al. 2012), the support of novel ecosystems (Hobbs, Higgs, and Hall 2013; Hobbs, Higgs, and Harris 2009), and 'learning to love exotic species' (Marris 2011; see also, Atchison and Head 2013; Barker 2008; Davis et al. 2011). A few biologists have even begun to suggest that introgression can be seen as a creative, additional force 
Fredriksen - 'Of wildcats and wild cats' (author created pdf, post peer review)

for adaptation (Becker et al. 2013; Schwenk, Brede, and Streit 2008). While rewilding and novel ecosystems have captured the lion's share of media attention, in some ways it is this last suggestion that is most radical one, as it unsettles the place of the species as "the foundational ontological unit" of conservation biology and its related discourse of biodiversity (Braverman 2014, page 2).

In the field of conservation, the ordering of species in vast taxonomic archives like the IUCN Red List of Threatened Species ${ }^{\mathrm{TM}}$, ARKive and EDGE have become primary tools for monitoring biodiversity (Bowker 2005; Yusoff 2010; Braverman 2014, 2015). Such orderings, as Kathryn Yusoff (2010) notes, invite 'seeing and witnessing', drawing the observer into responsibility (cf. Haraway 2008) for Earth's many endangered species. But these orderings can also be construed as a mode of biopolitical control over nonhuman lives, enacting certain ecologies and hierarchies over others (Yusoff 2010) and separating valued lives from unvalued ones (Braverman 2014, 2015). Biopolitics, as described by Foucault (2003), involves the power to make live and let die through modern governance techniques and technologies of administration and scientific expertise. While Foucault applied biopolitics specifically to human populations, a growing number of scholars have used it to analyse conservation practices (e.g., Biermann and Mansfield 2014; Braverman 2014, 2015; Chrulew 2011; Friese 2013; Lorimer 2015; Lorimer and Driessen 2013b). Of particular relevance to the field of conservation is the role of biopolitics in separating out valued lives to be fostered from unvalued ones to be left to die or even actively eliminated, both in order to secure the life of the species (Foucault 2003). Whereas in human biopolitics, the subversion of the individual to the population or species is often hidden from plain view, in conservation biology it is both explicit and fundamental. This is most apparent in the sacrifice of individual animals in captive breeding programmes (e.g., Braverman 2015, Chrulew 2011, van Dooren 2014) and the culling of more common, 'non-native' or 'pest' species to protect 'native' fauna (Marris 2011, van Dooren 2011). Such violence against individual animals is permissible, even desirable, in species-based conservation because within this ethical frame the moral significance of individual animals is erased, subsumed to the category of the species (Ansell-Pearson 1999). This allows the latter to then enter conservation discourses as a unitary moral entity, leading to the peculiar situation in which, as Smith writes, "we say 
Fredriksen - 'Of wildcats and wild cats' (author created pdf, post peer review)

that the Steller's sea cow was hunted to extinction, in much the same way we might say that the vicar has succumbed to gout" (2014, no page). Naturally, within this species focus there is no room for animals that fall between species categories. With rare exception (see Braverman 2015), hybrid animals are framed as threats to biodiversity (Biermann and Mansfield 2014) and thus along with animals deemed redundant, abundant or otherwise threatening to valued species, their lives are marked as having no conservation value.

Relatedly, conservation biology focused on the preservation of species and biodiversity tends, as others have noted, to essentialise the current collection of species on earth (Bowker 2005, Lorimer 2015). This outlook, Smith points out, bears a striking resemblance to the creation story of Genesis, wherein "God looked upon his work and deemed it good, and what ensued was a stable order of fixed, discrete, and well-bounded kinds, with no relations of descent among them" (2014, no page). Although the creator has been dispensed with and relations of descent (i.e., evolution) are embraced, in mainstream conservation biology species kinds "are still deemed good, intrinsically good, and if they do not remain fixed and unchanging, then we may conclude that something is out of order" (Smith 2014, no page). Thus species-based conservation not only elevates valued species above unvalued individuals, but also seeks to preserve a certain, clearly defined and unchanging version of the valued species. In other words, species-based conservation works against what Braun (2008) calls 'inventive life', that is life conceived in terms of immanence and potential becomings rather that in static, set forms or essential categories (see also Lorimer 2015, Lulka 2004). As the case of Scottish wildcat conservation demonstrates, this mode of conservation tries to freeze the movement and generative possibilities of wild life (Braverman 2015, Lorimer 2015). At the same time, as this case will also demonstrate, this attempt at purity is troubled by the unruly, muddled mixings of wild-living cats in Scotland.

\section{Placing cats: biogeographies of wild-living cats in Britain}

Scottish wildcats are not a unique species of cat, but rather a member of the European subspecies of the wider wildcat species (a matter discussed in detail below). Notably, European wildcats are not considered endangered and wildcats overall are common 
Fredriksen - 'Of wildcats and wild cats' (author created pdf, post peer review)

throughout Europe, Asia and Africa and thus listed as 'least concern' on the IUCN Red List. Nonetheless, Scottish wildcats are critically endangered at the national level and thus at risk of national extinction. Accordingly, in September 2013 Scottish Natural Heritage (SNH, an organisation funded by the Scottish government) launched its Scottish wildcat Conservation Action Plan (SWCAP). Various parts of the SWCAP are discussed throughout this article. First though, this section situates Scottish wildcats and the SWCAP by way of a brief review of the biogeography of wild-living cats in Britain.

Wildcats once ranged throughout Britain. Centuries of deforestation and hunting, however, led to the local extinction of wildcats from southern England as early as the $16^{\text {th }}$ century (Langley and Yalden, 1977). Continued habitat loss, hunting for furs throughout the centuries, and the rise of sporting estates from the mid-19th century onward with the associated rise in predator persecution, led to the local extinction of wildcats from England and Wales by 1880 (Langley and Yalden 1977; Tapper 1992). As the 20 th century began, wildcats were on the verge of extinction from Britain, confined to dwindling populations in the remote northwest Scottish highlands (Langley and Yalden 1977; Macdonald et al. 2010; Macdonald et al. 2004). A relative recovery of the Scottish wildcat population throughout the highlands in the 1920s has been attributed to the sequential events of the First World War, which significantly reduced the number of working gamekeepers, and the subsequent establishment of the forestry commission in 1919, which significantly increased woodland habitats in Scotland (Beaumont et al. 2001). Notably, some experts suspect that the assumed recovery of wildcat populations around this time may actually be the result of an upswing in hybrid populations due to increasing populations of feral cats in the region (Interview 3/3/14).

Today, wildcats are again on the verge of extinction in Britain. For a start, Scottish wildcats continue to suffer from habitat loss and fragmentation (Easterbee, Hepburn, and Jeffries 1991; Stahl and Artois 1994; Macdonald et al. 2004; 2010). For example, although there is suitable habitat for wildcats in southern Scotland and parts of northern England, Scotland's industrialised Central Belt (stretching east-west from Edinburgh to Glasgow) creates an effective barrier to wildcat migration to these areas. This problem of fragmentation is expected to worsen when plans to turn the A-9 - a road running northsouth through the Scottish highlands - into a dual carriageway go forward (interviews, 
3/3/14 and 5/3/14). In addition, and despite the Scottish Gamekeepers Association's involvement as stakeholders in the SWCAP, wildcats continue to suffer from persecution on hunting estates. As potential predators on pheasant and grouse moors wildcats are killed 'incidentally' by indiscriminate methods of predator control such as snares and 'lamping', a method of hunting at night using bright lights to detect eyeshine (Macdonald et al. 2010; Macdonald et al. 2004). Compounding the use of such indiscriminate methods of predator control, efforts to halt the illegal killing of wildcats on hunting estates are constrained by the difficulty in distinguishing between wildcats and tabby coated feral or collarless domestic cats and hybrids, which may be legally 'controlled' (that is, killed).

However, although habitat fragmentation and predator persecution on hunting estates are routinely noted as threats to Scottish wildcats, the larger threat, as noted above, is identified by the SWCAP as hybridisation with feral domestic cats. Notably, although there are only an estimated 400 Scottish wildcats left, the total wild-living cat population in Scotland - which includes wildcats, feral domestic cats and hybrid cats - numbers in the several thousands (Kilshaw et al. 2010; Scottish Natural Heritage 2013).

\section{Cats in and out of place}

Applying the sensibility of the Anthropocene to Scotland, McMorran et al note, "[a]ll Scottish landscapes are cultural landscapes, the product of thousands of years of interaction between human society and the biophysical environment" (2008, p. 194). At the same time, they also write that

\footnotetext{
it is nevertheless the case that a sense of wildness - a perception of 'nature in charge' - can still be experienced in large tracts of Scotland's countryside, and it is perhaps the preservation of this elusive quality which is a prime motivation for the preservation of the places where it can best be encountered. (ibid.)
}

Indeed, given the prevalence of wildcats outside of Britain and their absence from other parts of Britain, the preservation of a sense of particularly Scottish wildness is central to Scottish wildcat conservation. ${ }^{3}$ In the context of species-based conservation coupled with

\footnotetext{
${ }^{3}$ It is perhaps not coincidental that the development of the SWCAP coincided with the rise of the Scottish National Party and the lead-up to the Scottish referendum on independence. Suggestively, in a 2008 documentary on Scottish wildcat conservation, naturalist Mike Tomkies tells us that Scottish wildcats
} 
a national(istic) drive to cultivate a particularly Scottish 'sense of wildness', the difference between Scottish wildcats and feral domestic cats - undoubtedly of little concern to the cats themselves, not to mention to the rodents and rabbits they prey on - gains salience. That is, in this context, the lives of Scottish wildcats are highly valued while their feline cohabitants and potentially hybrid offspring are rendered as valueless threats to the preservation of the species. Underlining this point, an expert on Scottish wildcat conservation stated that the feral cat population in some Scottish habitats was so large that "leaving a good [wild]cat out there would actually be of no conservation value whatsoever" (Interview 5/3/14).

It is worth noting here that feral and hybrid cats are not deemed valueless simply because people don't like them - indeed, original plans for a cull of feral and hybrid cats were scrapped in favour of the less efficient and more expensive trap-neuter-release (TNR) programme because the former was deemed unpalatable to the public (interviews, 3-3-14; 5-3-14). Rather, the devaluing of feral and hybrid cats stems from their framing as out of place (van Dooren 2011) in the areas they cohabitate with 'native' wildcats, despite filling a similar ecological niche. In terms of their role in the ecosystem, wildcats give birth to smaller litters less often than feral or hybrid cats (Mike J. Daniels et al. 2002) and they are less likely to live in close proximity to human settlements (Germain, Benhamou, and Poulle 2008; Silva et al. 2013), but otherwise the groups seem to have similar habits. When pressed to explain how feral and hybrid cats could be bad for the ecologies of the Scottish highlands when wildcats are good for them, however, a leading wildcat conservationist seemed puzzled by the question, replying, as if it were clearly obvious, that "they're not supposed to be in that environment" (interview 3/3/14). In summary, feral cats in Scotland, as elsewhere (see van Patter 2015), are seen as out of place in the 'wild' and thus framed as threats to the preservation of 'pure' Scottish wildcats and the 'native' Scottish landscape more broadly.

While the imagined divide between wildcats, feral cats and hybrids is very clear, however, the reality is that these three types of wild-living tabby cats can be very difficult to distinguish from one another in practice. Camera traps, roadkill surveys and amateur

"epitomise what it means to be free, independent character", which he contrasts to humans who have "surrendered so many freedoms" (Piper, 2008). 
sightings have all been useful tools for establishing the presence of wild-living cats in the Scottish highlands. But whether these wild-living cats are wildcats, feral cats or hybrids is often unclear. As seasonality is not easily evident outside of long-term observation and one cannot be sure whether a large tabby cat spotted near a barn is a wildcat or not and even less so a cat spotted far from any human settlement, known behavioural differences are not very useful for conservation purposes. A first step in making Scottish wildcats present for the purposes of conservation (Hinchliffe 2008), then, has been to develop ways of distinguishing them from other cats through the scientific work of taxonomic ordering based on morphological and genetic traits. This work is the subject of the next section.

\section{Herding cats: ordering wildcats in taxonomic space}

The work of ordering the genus Felis is complicated by the closeness of its members' biology - most species assigned to the genus Felis can interbreed (Faure and Kitchener 2009). Ordering the wildcat species, Felis silvestris, is further complicated by the relatively recent domestication of cats from its ranks and the ongoing intermixing between domestic cats and wildcats. As a much cited analysis of the relationship between domestic and wildcats notes

The imprecise subspecific status of F. silvestris populations and of the relationship of the domestic cat within this assemblage stems from morphological similarities among these groups. A feral domestic cat with a 'wild-type' mackerel tabby pattern is difficult to distinguish visually from a 'true' wildcat, which is further confounded by ongoing admixture. (Driscoll et al. 2007)

Thus, the work of making Scottish wildcats present is not only the work of identifying where they are physically located in the Scottish landscape, but also of making them present in the representational space of taxonomic orderings. Where Scottish wildcats begin and end within the unruly assemblage of wildcats, domestic cats and hybrid cats has been, as this section explores, a central problem for their conservation.

\section{Making wildats present in taxonomic space}


Fredriksen - 'Of wildcats and wild cats' (author created pdf, post peer review)

The genus Felis comprises a handful of closely related species of small cats. Among its wild-living members, the genus includes Felis chaus (jungle cats), Felis nigripes (black-footed cats), Felis margarita (sand cats) and Felis silvestris (wildcats). A fifth member of the genus Felis, the Chinese steppe cat, was recently reclassified from a distinct species, Felis bieti, to a sub-species of the wildcat, F. silvestris bieti based on a molecular analysis that also added the southern African wildcat (F. s. cafra) to three already recognised subspecies of $F$. sylvestris: North African wildcats (F. s. lybica), Asian wildcats (F.s. ornata) and European wildcats (F. s. silvestris) (Driscoll et al. 2007). First classified as its own species, Felis grampia, by Miller in 1907, the Scottish wildcat was soon reclassified by Miller in 1912 as the subspecies F. s. grampia. Current analyses have not been able to find any clear distinction between Scottish wildcats and other European wildcats (Macdonald et al. $2010,481)^{4}$ such that today they are generally considered to comprise the same subspecies, F. s. silvestris. However, among those interested in the conservation of Scottish wildcats, the distinct designation of F. s. grampia is still sometimes mobilised.

The question of where domestic cats fit within the Felis genus is a matter of some debate. Tellingly, the differences found between wildcats and domestic cats in genetic analyses have been less than those found between different breeds of domestic dogs (Mike J. Daniels and Corbett 2003). Officially, domestic cats are classified as a separate species, Felis catus. Yet, along with all of the official members of Felis silvestris, domestic cats can interbreed with wildcats to produce healthy, fertile offspring (e.g. Gray 1972; A. C. Kitchener and Rees 2009), leading some experts to suggest that they might be more appropriately classified as a subspecies of the former - as F. s. catus. Indeed, Felis silvestris is the wild ancestor of today's domestic cats. Long thought to have been first domesticated by the Egyptians about 4000 years ago from African wildcats (F. s. lybica), recent analyses suggest cats were first domesticated much earlier, about 9000 years ago, in the fertile crescent, although still from F.s. lybica (Driscoll et al. 2007; Faure and Kitchener 2009). In either case, the domestication of cats was still relatively recent in evolutionary time - compare 4000-9000 years ago, for example, to the domestication of the dog, currently placed at 18,800-32,100 years ago (Thalmann et al. 2013). These early

\footnotetext{
${ }^{4}$ This is not surprising, as the population of wildcats in Britain only became separated from the European wildcat at the end of the last ice age, about 7000-9000 years ago - a relatively short time in terms of mammalian speciation (Yalden 1999).
} 
domesticated cats spread throughout the world through trade, and evidence from mitochondrial DNA (mtDNA) of today's domestic cats suggests that, as they spread they also interbred with local wildcat populations, such that the 'event' of cat domestication was distributed over time and space (Macdonald et al. 2010, 476). Moreover, as evidence from archaeological finds suggests, "in the early Neolithic, the boundary between domestic cat and wildcat was probably fine and variable" (Faure and Kitchener 2009, 226).

As domesticated cats spread through Europe and Asia, the hybridisation and introgression of wild and domestic cats continued. In Britain domestic cats were long assumed to be brought by Romans 2000 years ago, although recent Iron Age finds suggest they may have been present even earlier, 2586-3200 years ago (Faure and Kitchener 2009). But whether domestic cats arrived with Romans or earlier, they would have been living in sympatry with British wildcats - and therefore potentially interbreeding - for at least 2000 years before the 'type specimen' of the Scottish wildcat was first collected and classified in 1904 (Beaumont et al. 2001; Mike J. Daniels and Corbett 2003; Andrew C. Kitchener et al. 2005) ${ }^{5}$. As such, scientists cannot rule out the possibility that early scientific classification and description of the Scottish wildcat - as well Scottish wildcat museum specimens - may be of introgressed cats. Similarly, one cannot simply turn to historical accounts of wildcats to verify the characteristics of a 'pure' wildcat, as such accounts may also be of introgressed cats (Macdonald et al. 2010). Rather than accept the impossibility of fully separating wildcats from domestic cats, however, scientists have turned to ever more sophisticated techniques for drawing the two apart. In addition to attempts to distinguish wildcats from domestic cats and their hybrids based on morphological characteristics such as pelage (coat) patterns, body measurements, gut lengths and skulls characteristics (M. J. Daniels et al. 1998; Kilshaw et al. 2010; Andrew C. Kitchener et al. 2005; Schauenberg 1977; Yamaguchi et al. 2004), scientists are increasingly turning to advanced genetic analyses of both mtDNA and nuclear microsatellites (Beaumont et al. 2001; Beaumont et al. 2001; Driscoll et al. 2007; Kilshaw et al. 2010; O’Brien et al. 2009; Oliveira, Godinho, Randi, and Alves 2008;

\footnotetext{
${ }^{5}$ 'Type specimens' are generally the first named specimen of a species and generally held as representative of said species.
} 
Oliveira, Godinho, Randi, Ferrand, et al. 2008). In all of these attempts to distinguish morphologically or genetically wildcats from domestic cats - and thereby mark out clearly separate taxonomic spaces for them - there is a cline from cats most similar to known domestic cats to those furthest from them (and therefore assumed to be wildcats). In addition, these various modes of differentiating cats - from gut lengths to mtDNA each suggest different boundaries for dividing wildcats from domestic cats, with none completely coinciding with the other, as is indicative of a heavily introgressed population (Macdonald et al. 2010, 483). Moreover, the use of different genetic and morphological techniques produces different understandings of hybridity: the cats identified as close wildcat hybrids in continental Europe are different from those identified as the same in the UK. As one of the UK's leading scientific experts on Scottish wildcats explained,

I haven't understood this [difference between UK and continental genetic classifications of wildcats] until quite recently, but it's related to the genetic tests that they've been using. So, for example, in Germany they've been using microsatellites, but this can only tell you about hybridisation going back sort of one, two, three generations and thereafter it can't tell you whether something's a hybrid. Now I think that most of our hybridization events happened 100, 150 years ago, in which case it isn't going to pick that up. But pelage has proven to be much more sensitive to picking up that [with hybridisation] you get a distortion of the normal pelage variation. (Interview 3/3/14)

Thus the identity of a wild-living cat in taxonomic space will be different depending on whether it is determined by looking at the cat's mtDNA, its nuclear microsatellites or its pelage. This inability to find a clearly demarcated taxonomic space for Scottish wildcats, in turn, troubles the biopolitical orderings central to species-based conservation.

\section{Trees, rhizomes and the practicalities of species-based conservation}

The representational form through which the taxonomic orderings described above are imagined is that of an evolutionary 'tree of life'. In this familiar representational form, species branch from common ancestors in increasingly numerous lines. The pattern of division is linear and separation points are definite: species do not revert to previous forms or intermix once a branching is made (Bowker 2005). Evolutionary biologists and taxonomists of course recognise that this is not strictly how speciation works. Indeed, - it is through the scientific work described above that we know that domestic cats did not 
simply branch off from Felis silvestris lybica approximately 9000 years ago as a single event, but instead followed an irregular pattern of spatial and temporal separation and reconnection as domestication spread throughout Europe and Asia. Considering the muddled divisions between various cat forms and their ongoing intermixture, however, one cannot escape the conclusion that the genus Felis is poorly represented by the sparing order of the 'tree of life'. Wild-living cats in Scotland, with their interfolded histories and ongoing relations of kinship, escape the easy biopolitical ordering sought by genetic and morphological work to categorise them taxonomically.

The blurry separations, mixings and foldings of the members of the genus Felis traced by biologists thus suggest something more like a disorderly rhizome than a tree. Instead of the linear movement and definite dividing points of tree branches there are non-linear backfoldings, fragmentations and regenerations in unexpected directions (Deleuze and Guattari 1987). In this imagined rhizome of life species are represented less as distinct and definite types and more as ongoing processes of inventive life (Hinchliffe 2008; van Dooren 2014).

Yet, however appealing a rhizome of life might be from the perspective of accounting for the messy actualities of living bodies and generations, understanding species as processes complicates the work of conservation (Hinchliffe 2008). If wildcats cannot be neatly separated from feral cats and hybrids then how should conservation practices proceed? And if the line is not drawn at all and wildcats and feral domestics are left to mix and evolve freely, what are the consequences for the practical task of protecting wild-living cats in Scotland? Such questions have not escaped those working for Scottish wildcat conservation. Commenting on this matter, a conservation biologist working on Scottish wildcats reflected

in terms of values it's quite interesting because you might say now look, one of the sort of cut off points in genetic testing might be that its $95 \%$ pure and if you get $95 \%$ or above you might call it a wildcat, therefore if it's at $94 \%$ it's not a wildcat and therefore it's valueless. So, it's quite interesting how, trying to set arbitrary - to some extent arbitrary - but effective limits on what is or what isn't a wildcat, but you kinda have to because you've got to be pragmatic about it. So a $94 \%$ wildcat may only be marginally less valuable than a $95 \%$ or $96,97 \%$ one, but, hey, you've got to draw a line somewhere. (Interview 3/3/14) 
Fredriksen - 'Of wildcats and wild cats' (author created pdf, post peer review)

Although as a scientist it is recognised that any set line drawn between wildcats and nonwildcats will be at least partly arbitrary, as a conservationist there is still a felt need to draw a line: "you've got to draw the line somewhere".

And, indeed, while the difference between wildcats and domestic cats "may be academic in the face of their coexistence" (Mike J. Daniels and Corbett 2003, 214; see also IUCN Red List 2013; Macdonald et al. 2010), there are a number of practical reasons for the persistence of the current classification of the two as separate species and for ongoing work to find a definitive way to distinguish between them. For a start, drawing wildcats apart from the mundane domestic cat is a strategy for placing them within public imaginaries of wild(er)ness (see above), and thus enhancing public support for wildcat conservation efforts. In addition, as noted by Macdonald et al (2010: 478), such "taxonomic niceties" as separating wildcats from domestic cats have serious implications for the legal protection of wildcats. Under current UK and EC legislation, members of the classification Felis silvestris are highly protected while those of Felis catus and their hybrids are legally killable. ${ }^{6}$ Therefore identifying a way to differentiate wildcats from feral and hybrid cats, however artificial, is essential for ensuring the enforceability of their legal protection under current legislation. The drive among conservation biologists to delineate a distinct taxonomic space for Scottish wildcats, then, is not necessarily a matter of uncovering some biological 'truth', but rather a pressing legal and procedural matter (Macdonald et al 2010: 480).

To this end, alongside genetic testing, conservation biologists have developed a simple rapid identification tool for distringuishing between Scottish wildcats, feral cats and hybrids (see Figure 1). Among other uses, this '7PS' (for 'seven pelage characteristics') diagram was distributed in the form of pocket-sized, laminated cards to gamekeepers as part of the Cairngorms Wildcat Project (a precursor to the nation-wide SWCAP running from 2009-2012). After all, regardless of legal protections, if gamekeepers can't easily differentiate between legally protected wildcats and the numerous feral cats and hybrids that they may legally kill, it bodes ill for the welfare of the former.

\footnotetext{
${ }^{6}$ Scottish wildcats are protected by the UK's Wildlife and Countryside Act 1981, as well as by the EC Habitats directive 1992, however wildcat/feral cat hybrids are not since a 2002 proposal to protect such mixed cats under the Wildlife and Countryside Act was rejected.
} 
Figure 1: Seven key pelage characteristics (7PS) to distinguish between Scottish wildcats (A) and feral domestic tabby cats and wildcat $x$ feral cat hybrids (B)

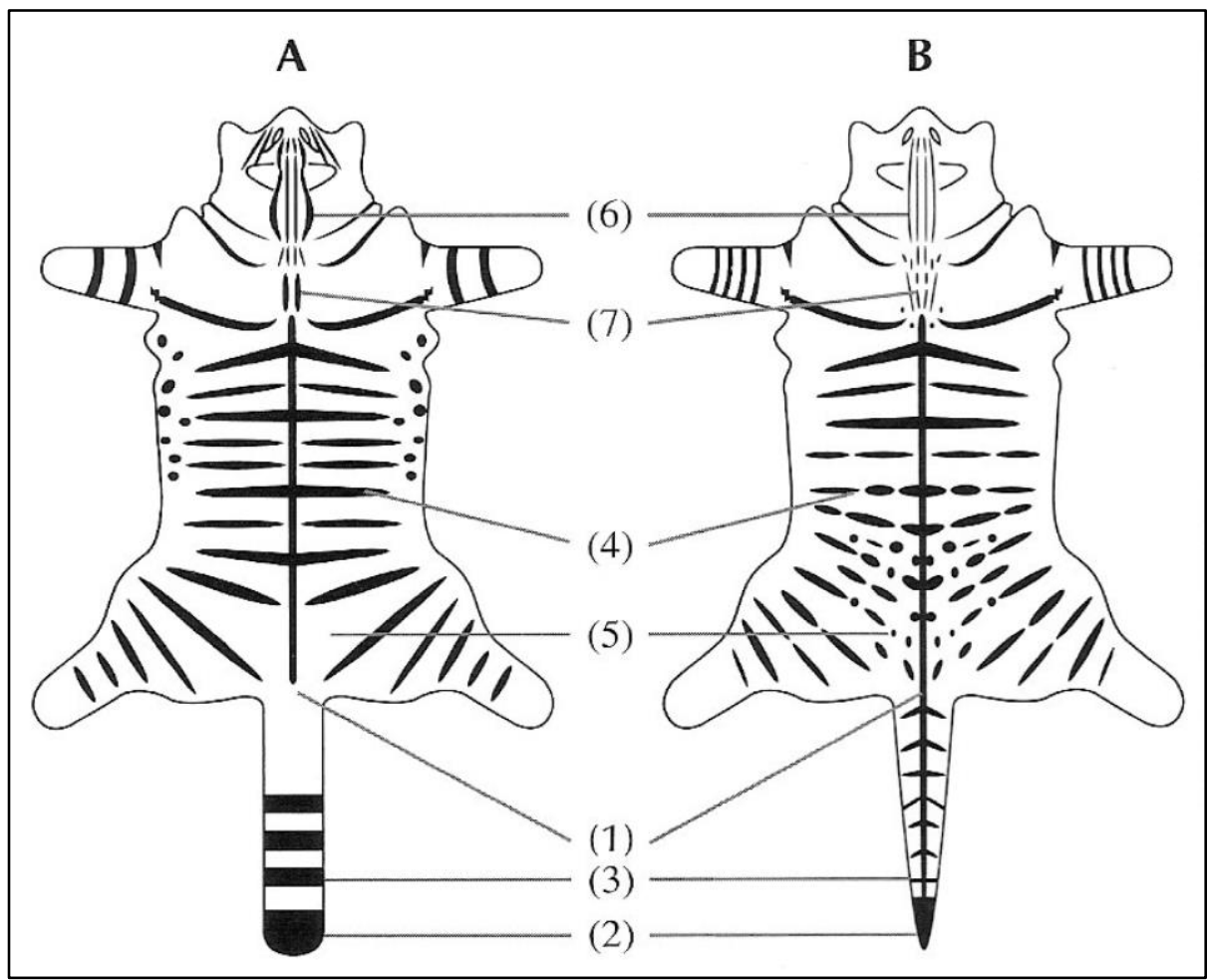

Source: Macdonald et al. 2004, adapted from Kitchener et al. 2005

There is, of course, a performative aspect to all of this scientific and conservation work (Lorimer 2015). That is, species-based conservation and the biopolitics of valued and unvalued life it fosters work to preserve a particular type of Scottish wildcat to the detriment of potential others. The sub-species type of Scottish wildcats is made present through the cumulative biopolitical work of defining its form and, of course, making present always also makes some things absent (Hinchliffe 2008; Callon and Law 2004; Hetherington 2004). Cats enrolled in the SWCAP's proposed Scottish wildcat captive breeding programme, to which I now turn, will need to both pass genetic screening tests and meet the 'strict ID' criteria of the 7PS (Scottish Natural Heritage 2013).

Multiplying cats: captive breeding and the prioritisation of form over bodies 
The development of a captive breeding programme for Scottish wildcats is a key element of the SWCAP. The programme would ostensibly be aimed at achieving 'population reinforcement' through reintroductions of captive bred wildcats to suitable non-captive habitats. However, while the priority assigned to captive breeding in the SWCAP is 'high', the priority assigned to even "a trial release of captive cats to assess their ability to adapt to a wild-living situation" is low (Scottish Natural Heritage 2013, 6).

Once a suitable number of wildcats have been brought into the captive breeding programme from the wild, a captive population can be established through managed breeding and maintained indefinitely until which time release back into the wild is deemed suitable. Release into the wild, however, as the director of one of SNH's identified 'key sites' for captive breeding noted, is unlikely to happen for some time as the conditions threatening the survival of a 'pure' wildcat type in the wild - namely the copresence of feral and hybrid cats - are likely to persist into the foreseeable future. Thus, the director explained,

Any release or reintroduction that takes place at some undefined point in the future will probably be in areas that have been heavily controlled and they're able—because I would have serious problems if I went through all the effort of managing a captive programme and we had a very healthy population of 200, 250 cats and then we were starting to produce animals for release that end up running into exactly the same problems. ... but we're a long long way away from doing that [releasing captive bred cats]. (Interview, 5/3/14)

The value of the captive breeding programme, it seems, is not necessarily in the prospect of replenishing the wild stock of 'pure' wildcats, but rather as a sort of bodily or genetic insurance policy for the species (Soule et al. 1986). Reflecting this understanding, the director explained,

The value of the captive programme in realistic terms as I see it is that if we establish a pure bred or as near as we see as a purebred cat population in a captive environment under the stewardship of a coordinated breeding programme, that is the only $100 \%$, sure fire, absolutely guaranteed way of saving the Scottish wildcat ... I'm really confident that the captive programme will do exactly what it says on the tin. I am not so confident we'll be as successful, certainly not in the short term, with conserving the animal in the wild or creating enough habitat that is safe for wildcats to go back into. (Interview, 5/3/14) 
Captive breeding, then, is yet another mode of separating wildcats from feral cats and hybrids - valued lives from unvalued ones. Whereas the practices identified above involved separating wildcats from feral and hybrid cats in the abstract space of taxonomy, the captive breeding plan involves separating cats in physical space, removing those deemed to be valuable for the preservation of the 'pure' wildcat form from the places they share with the unvalued feral and hybrid cats that threaten this form. As one expert on Scottish wildcats suggested, given their situation vis-à-vis feral and hybrid cats, the best course of action would be to capture as many 'true' Scottish wildcats from the wild as possible and bring them into the 'safe' space of a captive breeding programme, as was done with the California condor and the black-footed ferret in North America. The alternative, he suggests would be to "just talk about it until it becomes extinct" (interview 3/3/14). California condors and black-footed ferrets, however, were not hybridising with more common animals, but were at risk of extinction full stop. The idea of rescuing Scottish wildcats from other wild-living cats with which many share relations of close recent and historical kinship, poses questions not immediately apparent for California condors and black-footed ferrets, namely about animal agencies and their role, or lack thereof, in species-based conservation.

\section{The prioritisation of form over bodies}

The irony of the wildcat captive breeding programme would be, of course, that by attempting to conserve a 'pure' version of the Scottish wildcat, the very thing that is prized about the wildcat is lost: its wildness. While one must be cautious of fetishizing wild-living - as the director quoted above noted, "no animals die in their bed in the wild" (interview 3/3/14) - one should also consider what it means to breed Scottish wildcats (or any species) in captivity without any definite plans for release. Besides the obvious condition of captivity, captive breeding programmes rely on practices - most notably the studbook - developed for the pure-breeding of domestic animals like dogs and horses to ensure the careful management of lineages and thus bodily (and genetic) forms. At a very basic level, then, captive breeding for conservation is a process of human-controlled, selective breeding: the basic process of domestication (Cassidy 2007). Conversely, the interbreeding of wildcats with feral domestic cats and hybrids mirrors more closely what 
Fredriksen - 'Of wildcats and wild cats' (author created pdf, post peer review)

we think of when we imagine wildness: animals acting on their own agency, without direct human interference.

Captive breeding programmes are managed to foster a particular, valued species, generally conceived abstractly as an ideal genetic and/or morphological 'type'. This type, as Haraway reminds us, is not something pre-determined by 'nature' or fixed in reality, but something conceived by humans, "a living, imaginative hope and memory" (Haraway 2008, 148; see also Lulka 2009). Animals that don't help foster this ideal type are culled or sterilised. Thus the species type, an abstraction represented by the further abstraction of genes, is elevated above fleshy, embodied animals emplaced in dynamic ecologies and living landscapes (Ansell-Pearson 1999; Chrulew 2011; Lulka 2004). The result is that the biopolitical work of species conservation takes on the hygienic task of separating the 'pure' from the 'impure'. Indeed, as one scientific assessment of introgression between wild- and feral cats puts it, "a continuous backcrossing of hybrid individuals to parental populations may eventually culminate in a deep and irreversible genetic pollution of wild populations" (Oliveira, Godinho, Randi, and Alves 2008, 2953 emphasis added; see also, Oliveira, Godinho, Randi, Ferrand, et al. 2008; Andrew C. Kitchener 2013). Translated into the more alarmist tones of popular media, a columnist for The Observer writes that " $[\mathrm{t}]$ he wildcat's imminent extinction may have been camouflaged from our consciousness by the existence of a counterfeit cat - a feline facsimile that looks like a wildcat but whose genealogy is far from pure ... The government masterplan [for wildcat conservation] is as fake as the DNA of the hybrids masquerading as pure-bloods" (McKenna 2013; see also Piper 2008).

Leaving aside the puzzling conclusion that DNA generated through the regular means of unaided sexual reproduction might be 'fake', this discourse of the threat of 'genetic pollution' to the 'pure' lineage of the Scottish wildcat lays bare the ultimately eugenicist workings of the biopolitical parsing of valued and unvalued lives in the conservation of species as such.

\section{Conclusion}


This paper has taken the case of Scottish wildcat conservation as a site for exploring what it means to conserve species as such. As illustrated above, in centring conservation efforts on the preservation of a fixed and abstracted species (geno)type above and at times to the exclusion of care for individual animals, species-based conservation enacts a form of violence against the unfolding intergenerational relationships of wild-living cats as they engage in unruly inter-bodily mixings. Advocates of preserving genetically pure Scottish wildcats may appeal to the interests of the wildcats themselves, whose unique genetic and morphological type may be lost amongst a hybrid swarm. But we can only assume that wildcats are perfectly happy to carry on interbreeding with feral cats and hybrids without human interference and are not themselves concerned about preserving any particular genetic or morphological types so long as they can pass their own genes along to the next generation through successful reproduction.

One of the fundamental ironies of the biodiversity discourse at the heart of species-based conservation is that the inclusiveness implied by the term is lost through practices that produce systematic exclusions (van Dooren 2011). In the case of Scottish wildcat conservation, the pursuit of 'native' Scottish biodiversity involves the attempt to stamp out 'non-native' feral cats and the hybrids that muddle these categories. Importantly, however, it is not simply individual animals rendered valueless that suffer here, but the generative possibilities of life left to its own devices. By taking wildcats out of the wild and into zoos and wildlife sanctuaries for captive breeding and reducing the population of wild-living cats through TNR programmes for feral and hybrid cats, we risk impoverishing our wild spaces in the name of conserving specific geno-types, irrespective of the particular ecological niches the living animals in question might fill in the rapidly changing environment of the Anthropocene.

It should be emphasised that the argument here is decidedly not one for inaction in the midst of the ongoing cascade of anthropogenic extinctions and accelerated defaunation. There are cases where captive breeding or other intensive management techniques may be the best way to care for groups of ostensibly wild animals. But the case of Scottish wildcat conservation illustrates some of the fundamental inadequacies of the blanket application of the techniques of species-based conservation. This point is not lost on conservationists. In their review of the 'history, past and present' of Scottish wildcats, 
David Macdonald and colleagues write that "the predicament of this species illustrates, in microcosm, fundamental questions in both the science and ideology of species' conservation" (Macdonald et al. 2010, 472). Despite reflection, however, the (sub)species-based conservation of Scottish wildcats moves forward because conservationists must deal with the practicalities of an often disinterested public and the paucity of endangered species protections under the law. With this in mind, this article is also not a 'take-down' of wildcat conservationists. The argument here is, however, a call to re-examine the priorities of conservation in the face of cascading extinctions and rapid defaunation in the Anthropocene.

Rather than trying to freeze a snapshot of valued species-types, while turning our backs on animals that are threatening to, more common than, or redundant members of valued species, conservation initiatives in the Anthropocene should be forward looking and open to supporting changing wildlife populations and animal autonomy, especially in cases where this would encourage wildlife regeneration, flourishing ecosystems and the recovery of animal abundance. With this approach in mind, feral domestic cats and wildcat-domestic cat hybrids could be seen not as the primary threat to Scottish wildcats, but as contributing to the reconstitution of a flourishing population of wild-living cats in Britain.

Acknowledgements: This paper is indebted to the professional and academic conservationists who took time out of their busy schedules to discuss Scottish wildcat conservation with me. Thanks is also owed to the audience and panel members at the 2015 RGS-IBG conference session on 'More-than-human geographies of conservation' and the participants of the Society and Environment Reading Group at the University of Manchester, SEED for their comments on earlier versions of this article. Thank you to the two anonymous reviewers and the journal editors for their helpful and generousspirited comments, which have greatly improved this article.

\section{References}

Ansell-Pearson K, 1999 Germinal Life: The Difference and Repetition of Deleuze (Routledge,London) 
Fredriksen - 'Of wildcats and wild cats' (author created pdf, post peer review)

Atchison J, Head L, 2013, "Eradicating Bodies in Invasive Plant Management" Environment and Planning D: Society and Space 31 951-68

Barker K, 2008, "Flexible Boundaries in Biosecurity: Accommodating Gorse in Aotearoa New Zealand" Environment and Planning A 40 1598-1614

Barnosky A D, Matzke N, Tomiya S, Wogan G, Swartz B, Quental T, Marshall C, et al, 2011, "Has the Earth's Sixth Mass Extinction Already Arrived?" Nature 471 51-57

Beaumont M, Barratt E M, Gottelli D, Kitchener A C, Daniels M J, Pritchard J K, Bruford M W, 2001, "Genetic Diversity and Introgression in the Scottish Wildcat" Molecular Ecology 10 319-36

Becker M, Gruenheit N, Steel M, Voelckel C, Deusch O, Heenan P B, McLenachan P A, Kardailsky O, Leigh J W, Lockhart P J, 2013, "Hybridization May Facilitate in Situ Survival of Endemic Species through Periods of Climate Change" Nature Climate Change 3 1039-43

Biermann C, Mansfield B, 2014, "Biodiversity, Purity, and Death: Conservation Biology as Biopolitics." Environment and Planning D: Society and Space 32 257-73

Bowker G C, 2005, "Time, Money and Biodiversity" in Global Assemblages: Technology, Politics, and Ethics as Anthropological Problems Eds A Ong, S J Collier (Blackwell, Oxford) pp 107-123

Braverman I, 2014, "En-listing life: red is the color of the threatened species list" SUNY Buffalo Legal Studies Research Paper No 2015-001. URL: http://ssrn.com/abstract=2496481

Braverman I, 2015, Wild Life: The Institution of Nature (Stanford University Press, Stanford)

Braun B, 2008, "Environmental issues: Inventive Life" Progress in Human Geography 32 667-679

Butler D, 1994, "Bid to Protect Wolves from Genetic Pollution" Nature 370497

Callon M, Law J, 2004, "Guest Editorial Introduction: Absence - Presence, Circulation, and Encountering in Complex Space" Environment and Planning D: Society and Space 22 3-11

Cassidy R, 2007, "Introduction: Domestication Reconsidered" In Where the Wild Things Are Now: Domestication Reconsidered Eds R Cassidy, M H Mullin (Berg, Oxford) pp 1-26

Castree N, 2005 Nature (Routledge, London)

Castree N, 2014, "The anthropocene and geography l: the back story" Geography Compass 8 436449

Castree N et al, 2014, "Changing the intellectual climate" Nature Climate Change 4 763-768

Chrulew M, 2011, "Managing Love and Death at the Zoo: The Biopolitics of Endangered Species Preservation" Australian Humanities Review 50 137-57

Cordingley J E, Sundaresan S R, Fischhoff I R, Shapiro B, Ruskey J, Rubenstein, D I, 2009, "Is the Endangered Grevy's Zebra Threatened by Hybridization?" Animal Conservation 12 505-13

Cronan W 1995 "he trouble with wilderness; or, getting back to the wrong nature" in W Cronan (ed) Uncommon Ground: Rethinking the Human Place in Nature (W. W. Norton, New York) 69-90

Daniels M J, Corbett L, 2003, "Redefining Introgressed Protected Mammals: When Is a Wildcat a Wild Cat and a Dingo a Wild Dog?" Wildlife Research 30 213-18

Daniels M J, Wright T C M, Bland K P, Kitchener A C, 2002, "Seasonality and Reproduction in WildLiving Cats in Scotland" Acta Theriologica 47 73-84 
Daniels M J, Balharry D, Hirst D, Kitchener A C, Aspinall R J, 1998, "Morphological and Pelage Characteristics of Wild Living Cats in Scotland: Implications for Defining the 'wildcat'" Journal of Zoology 244 231-47

Davis M A, Chew M K, Hobbs R J, Lugo A E, Ewel J J, Vermeij G J, Brown J H, et al, 2011, “Don't Judge Species on Their Origins" Nature 474 153-54

Deleuze G, Guattari F, 1987, A Thousand Plateaus: Capitalism and Schizophrenia, Trans Brian Massumi (Continuum, London)

Dirzo R, Young H S, Galetti M, Ceballos G, Isaac N J B, Collen B, 2014, "Defaunation in the Anthropocene." Science 345 401-6

Donlan J, 2005, "Re-Wilding North America" Nature 436 913-14

Driscoll C A, Menotti-Raymond M, Roca A L, Hupe K, Johnson W E, Geffen E, Harley E H, et al, 2007, "The Near Eastern Origin of Cat Domestication" Science 317 519-23

Easterbee N, Hepburn L V, Jeffries D J, 1991, "Survey of the Status and Distribution of the Wildcat in Scotland, 1983-1987" Nature Conservancy Council for Scotland, Edinburgh

Ellis E C, 2011, "Anthropogenic transformation of the terrestrial biosphere" Philisophical Transactions of the Royal Society A 369 1010-1035

Ellis E, 2015, "Ecology in an Anthropocene biosphere" Ecological Monographs 85 287-331

Faure E, Kitchener A C, 2009, "An Archaeological and Historical Review of the Relationships between Felids and People" Anthrozoos 22 221-38

Foucault M, 2003 Society Must Be Defended: Lectures at the College de France, 1975-1976 (Allen Lane, London)

Fredrickson R J, Hedrick P W, 2006, "Dynamics of Hybridization and Introgression in Red Wolves and Coyotes" Conservation Biology 20 1272-83

Friese C, 2013 Cloning Wildlife: Zoos, Captivity, and the Future of Endangered Animals (NYU Press, New York)

Germain E, Benhamou S, Poulle M-L, 2008, "Spatio-Temporal Sharing between the European Wildcat, the Domestic Cat and Their Hybrids" Journal of Zoology 276 195-203

Gray A P, 1972, Mammalian Hybrids: A Check-List with Bibliography (Commonwealth Agricultural Bureaux, Slough)

Haraway D, 1991, Simians, cyborgs, and women: the reinvention of nature (Routledge, New York)

Haraway D, Simians, cyborgs, and women: the reinvention of nature (Routledge, New York)

Haraway D, 2008, When Species Meet (University of Minnesota Press, Minneapolis)

Hetherington K, 2004, "Secondhandedness: Consumption, Disposal, and Absent Presence" Environment and Planning D: Society and Space 22 157-73

Hinchliffe S, 2008, "Reconstituting Nature Conservation: Towards a Careful Political Ecology" Geoforum 39 88-97

Hobbs R J, Higgs E, Harris J A, 2009, "Novel Ecosystems: Implications for Conservation and Restoration" Trends in Ecology \& Evolution 24 599-605

Hobbs R J, Higgs E S, Hall C, 2013 Novel Ecosystems: Intervening in the New Ecological World Order (Wiley-Blackwell, Oxford) 
Höflinger L, 2012, "Polar Bears And Grizzlies Producing Hybrid Offspring as Arctic Melts" Spiegel Online, March 10 URL: http://www.spiegel.de/international/world/polar-bears-and-grizzliesproducing-hybrid-offspring-as-arctic-melts-a-859218.html.

IUCN Red List, 2013, "Felis Silvestris (Wildcat, Wild Cat)" The IUCN Red List of Threatened Species URL: http://www.iucnredlist.org/details/8543/0.

Kilshaw K, Drake A, Macdonald D W, Kitchener A C, 2010, "The Scottish Wildcat: A Comparison of Genetic and Pelage Characteristics" Scottish Natural Heritage Commissioned Report No.356. (Scottish Natural Heritage, Edinburgh) URL: http://www.snh.org.uk/pubs/detail.asp?id=1466.

Kitchener A C, Rees, E E, 2009, "Modelling the Dynamic Biogeography of the Wildcat: Implications for Taxonomy and Conservation" Journal of Zoology 279 144-55

Kitchener A C, 2013, "Race against Time to Save the Wildcat" The Scotsman, 10 December, URL: http://www.scotsman.com/news/race-against-time-to-save-the-wildcat-1-3220826.

Kitchener A C, Yamaguchi N, Ward J M, Macdonald D W, 2005, "A Diagnosis for the Scottish Wildcat (Felis Silvestris): A Tool for Conservation Action for a Critically-Endangered Felid" Animal Conservation 8 223-37

Kolbert E, 2014 The Sixth Extinction: An Unnatural History (Bloomsbury, London)

Langley P J W, Yalden D W, 1977, "The Decline of the Rarer Carnivores in Great Britain during the Nineteenth Century" Mammal Review 7 95-116

Latour B, 1993, We have never been modern (Harvard University Press, Cambridge, MA)

Leakey R E, Lewin R, 1995, The Sixth Extinction: Patterns of Life and the Future of Humankind (Doubleday, New York)

Lorimer J, 2015, Wildlife in the Anthropocene: Conservation after Nature. Minneapolis, MN: University of Minnesota Press

Lorimer J, Driessen C, 2013a, "Wild Experiments at the Oostvaardersplassen: Rethinking Environmentalism in the Anthropocene" Transactions of the Institute of British Geographers 39 16981

Lorimer J, Driessen C, 2013b, "Bovine Biopolitics and the Promise of Monsters in the Rewilding of Heck Cattle" Geoforum 48 249-59

Lulka D, 2004, "Stabilizing the Herd: Fixing the Identity of Nonhumans" Environment and Planning D: Society and Space 22 439-63

Lulka D, 2009, "Form and Formlessness: The Spatiocorporeal Politics of the American Kennel Club" Environment and Planning D: Society and Space 27 531-53

Lunt I D, Byrne M, Hellmann J J, Mitchell N J, Garnett S T, Hayward M W, Martin T G, McDonaldMaddden E, Williams S E, Zander K K, 2013, "Using Assisted Colonisation to Conserve Biodiversity and Restore Ecosystem Function under Climate Change" Biological Conservation 157 172-77

Macdonald M W, Daniels M J, Driscoll C, Kitchener A C, Yamaguchi N, 2004, The Scottish Wildcat: Analyses for Conservation and an Action Plan (Wildlife Conservation Research Unit, The University of Oxford)

Macdonald D W, Yamaguchi N, Kitchener A C, Daniels M, Kilshaw K, Driscoll C, 2010, "Reversing Cryptic Extinction: The History, Present, and Future of the Scottish Wildcat" In Biology and Conservation of Wild Felids Eds D W Macdonald A J Loveridge (Oxford University Press, Oxford)

Marris E, 2011 Rambunctious Garden: Saving Nature in a Post-Wild World (Bloomsbury, New York) 
Fredriksen - 'Of wildcats and wild cats' (author created pdf, post peer review)

McKenna K, 2013, "Extinction by Stealth: How Long Can the Scottish Wildcat Survive?" The Observer, September 28, URL: http://www.theguardian.com/environment/2013/sep/29/scottish-wildcatextinction-by-stealth.

McLachlan J S, Hellmann J J, Schwartz M W, 2007, “A Framework for Debate of Assisted Migration in an Era of Climate Change" Conservation Biology 21 297-302

Mc Morran R, Price M F, Warren C R, 2008 "The call of different wilds: the importance of definition and perception in protecting and managing Scottish wild landscapes" Journal of Environmental Planning and Management 51 177-199

Miller K A, Miller H C, Moore J A, Mitchell N J, Cree A, Allendorf F W, Sarre S D, Keall S N, Nelson N J, 2012, "Securing the Demographic and Genetic Future of Tuatara through Assisted Colonization" Conservation Biology 26 790-98

O’Brien J, Devillard S, Say L, Vanthomme H, Léger F, Ruette S, Pontier D, 2009, “Preserving Genetic Integrity in a Hybridising World: Are European Wildcats (Felis Silvestris Silvestris) in Eastern France Distinct from Sympatric Feral Domestic Cats?" Biodiversity and Conservation 18 2351-60

Oliveira R, Godinho R, Randi E, Alves P C, 2008, "Hybridization versus Conservation: Are Domestic Cats Threatening the Genetic Integrity of Wildcats (Felis Silvestris Silvestris) in Iberian Peninsula?" Philosophical Transactions of the Royal Society B: Biological Sciences 363 2953-61

Oliveira R, Godinho R, Randi E, Ferrand N, Alves P C, 2008, "Molecular Analysis of Hybridisation between Wild and Domestic Cats (Felis Silvestris) in Portugal: Implications for Conservation" Conservation Genetics 9 1-11

Piper S, 2008, Last of the Scottish Wildcats, Coffee Films [format: DVD]

Rhymer J M, Simberloff D, 1996, "Extinction by Hybridization and Introgression" Annual Review of Ecology and Systematics 27 83-109

Schauenberg P, 1977, "Longueur de L'intestine Du Chat Forestier Felis Silvestris Schreber." Mammalia 41 357-60

Schwenk K, Brede N, Streit B, 2008, "Introduction. Extent, Processes and Evolutionary Impact of Interspecific Hybridization in Animals" Philosophical Transactions of the Royal Society B: Biological Sciences $3632805-11$

Scottish Natural Heritage, 2013, Scottish Wildcat Conservation Plan, (Scottish Natural Heritage, Edinburgh) URL:

http://www.snh.org.uk/pdfs/publications/wildlife/wildcatconservationactionplan.pdf.

Silva A P, Kilshaw K, Johnson P J, Macdonald D W, Rosalino L M, 2013, "Wildcat Occurrence in Scotland: Food Really Matters" Diversity and Distributions 19 232-43

Soulé M, Gilpin M, Conway W, Foose T, 1986, "The Millenium Ark: How Long a Voyage, How Many Staterooms, How Many Passengers?" Zoo Biology 5 101-13

Soulé M, Noss R, 1998, "Rewilding and Biodiversity: Complimentary Goals for Continental Conservation" Wild Earth 8 18-28

Stahl P, Artois M, 1994, "Status and Conservation of the Wildcat (Felis Silvestris) in Europe and around the Mediterranean Rim" Report no, 69 Council of Europe, Nature and Environment, Strasbourg

Stronen A V, Paquet P C, 2013, "Perspectives on the Conservation of Wild Hybrids" Biological Conservation 167 390-95

Tapper S, 1992, "Game Heritage" The Game Conservancy, Fordingbridge 
Thalmann O, Shapiro B, Cui P, Schuenemann V J, Sawyer S K, Greenfield D L, Germonpré M B, et al., 2013, "Complete Mitochondrial Genomes of Ancient Canids Suggest a European Origin of Domestic Dogs" Science 342 871-74

van Dooren T, 2011, "Invasive Species in Penguin Worlds: An Ethical Taxonomy of Killing for Conservation" Conservation and Society 9 286-98

van Dooren T, 2014 Flight Ways: Life and Loss at the Edge of Extinction (Columbia University Press, New York)

van Patter L, 2015 Exploring Human-Feral Cat Relations in Southern Ontario Unpublished MA thesis, Department of Geography, University of Guelph, Guelph, Canada

Ward J L, Blum M J, Walters D M, Porter B A, Burkhead N, Freeman B, 2012, "Discordant Introgression in a Rapidly Expanding Hybrid Swarm" Evolutionary Applications 5 380-92

Williams M, Zalasiewicz J, Haff P, Schwägerl C, Barnosky A D, Ellis E C, 2015, “The Anthropocene biosphere" The Anthropocene Review 2 196-219

Whatmore S, 2002 Hybrid Geographies (Sage, Thousand Oaks, CA)

Whatmore S, Thorne L, 1998, "Wild(er)ness: Reconfiguring the Geographies of Wildlife" Transactions of the Institute of British Geographers 23 435-454

Yamaguchi N, Kitchener A C, Driscoll C A, Ward J M, Macdonald D W, 2004, "Craniological Differentiation amongst Wild-Living Cats in Britain and Southern Africa: Natural Variation or the Effects of Hybridisation?" Animal Conservation 7 339-51

Yusoff K, 2010, "Biopolitical Economies and the Political Aesthetics of Climate Change" Theory, Culture \& Society 27 73-99

Zalasiewicz J et al, 2008, "Are we now living in the Anthropocene?" GSA Today 18 4-8 